\title{
A memória ferida na narrativa cubana atual
}

\begin{abstract}
Aimée G. Bolaños ${ }^{1}$
Resumen: La memoria herida en dos textos narrativos recientes de la literatura cubana, Inscrita bajo sospecha, de Mabel Cuesta, y El corazón del rey, de Félix Luis Viera (ambos de 2010), constituye el centro de este trabajo que, leyendo a Paul Ricoeur, indaga en las poéticas narrativas del ser interior y tiempo reencontrado. Me detengo en la memoria traumática de tiempos difíciles de esos autores en diáspora, focalizando la naturaleza de su ficción, los imaginarios de memoria/olvido, las formas de componer la narración en el movimiento rememorativo, sobre todo, relativas a la invención del sujeto y sus juegos temporales
\end{abstract}

Palabras claves: Memoria herida, ficción de la memoria, narrativa cubana actual, diáspora

Resumo: A memória ferida em dois textos narrativos recentes da literatura cubana, Inscrita bajo sospecha, de Mabel Cuesta, e El corazón del rey, de Félix Luis Viera (ambos de 2010), constitui o centro deste trabalho que, lendo Paul Ricoeur, indaga nas poéticas narrativas do ser interior e do tempo reencontrado. Detenho-me na memória traumática de tempos difíceis desses autores em diáspora, focalizando a natureza da sua ficção, os imaginários de memória/esquecimento, as formas de compor o texto narrativo no movimento rememorativo, sobretudo, no que diz respeito à invenção do sujeito e os jogos da temporalidade.

Palavras-chaves: Memória ferida, ficção da memória, narrativa cubana atual, diáspora.

\footnotetext{
1 Aimée G. Bolaños: Poeta e ensaísta. Professora da Universidade Federal do Rio Grande, Brasil, e da University of Ottawa, Canadá. Doutora em Filosofia, rama da Literatura Latino-Americana, pela Rostock Universität, Alemanha; Pós-doutora em Literatura Comparada pela Universidade Federal de Rio Grande do Sul (UFRGS), Brasil. Conferencista em diversas universidades européias e americanas. Publicações recentes: Pensar la narrativa (Brasil, 2002) y Poesía insular de signo infinito. Una lectura de poetas cubanas de la diáspora (España, 2008), ensaios. Seus estudos da poesia da diáspora cubana integram numerosos livros, entre eles: Vozes negras da literatura das Américas (no prelo). Participou no Dicionário das mobilidades culturais: percursos americanos (Brasil, 2010), organizado por Zilá Bernd. Poesia: El Libro de Maat (Brasil, 2002), Las Otras. Antología mínima del Silencio (España, 2004) y Layla y Machnún, el amor verdadero, (em coautoria, España, 2006), Las palabras viajeras (España, 2010).
} 
Así creo que es la vida. No un dogma, no un código, no una historia, sino un misterio que hay que atacar por distintos flancos.

No con el fin de desentrañarlo (lo cual sería horrible) sino con el fin de no darnos jamás por vencidos.

Reinaldo Arenas

El mundo alucinante

\section{Entrando no tema}

Como uma reserva identitária, que tem o poder de ressignificar os acontecimentos e a nós mesmos, apresenta-se a memória. Quando rememoramos, com os movimentos de recuperação e reconfiguração, fazemos da própria identidade e dos fatos históricos, eventos dinâmicos, em incessante transformação. Em tal sentido, a ficção se torna um extraordinário laboratório de formas do ser interior ao relatar um tempo humano, no qual convivem memória e esquecimento.

Interesso-me, então, por ficções da memória de sujeitos no labirinto de uma época traumática, seja revolução social, sociedade pós-revolucionária, exílio ou migração, quero dizer, ficções da memória ferida. E no reconhecimento desses tempos históricos de transformações radicais e cataclismos existenciais que tem marcado a história cubana dos últimos sessenta anos, não posso deixar de me lembrar de Borges quando, de modo sibilino, diz que lhe tocou viver (está se referindo ao seu pai), como a quase todos os homens, tempos difíceis, relativizando as dificuldades de cada tempo histórico, geralmente percebido pelo sujeito que obra e padece como o mais difícil. Então, aqui no umbral, confesso-me suspeita, partícipe dessas memórias de tempo recobrado, sendo minha leitura parcial e apaixonada, a de uma contemporânea e conterrânea desses escritores, também em diáspora.

Sobre ficção, imaginação e memória dos “tempos difíceis", penso a seguir, e principalmente pelo viés ricoueriano ${ }^{2}$, focalizando dois textos narrativos de publicação recente, já em circulação na cultura literária de nossos dias: Inscrita bajo sospecha, de Mabel Cuesta, y El corazón del rey, de Félix Luis Viera ${ }^{3}$.

\section{Memória da suspeita}

Inscrita bajo sospecha desafia a imaginação ativando memórias pessoais para compor uma experiência leitora. O livro de Mabel Cuesta ${ }^{4}$, formado por catorze fragmen-

2 Pode-se seguir o percurso do pensamento de Paul Ricoeur sobre memória em vários textos dos anos 90 . Ver: Une réponse de Paul Ricoeur. In: JOY, Morny (Ed.). Paul Ricoeur and Narrative. Context and contestation. University of Calgary Press, 1997, p. xlv-lv 1997; La marque du passé. Revue de Metaphysique et de Morale, n. 1, p. 7-31, 1998; La lectura del tiempo pasado: memoria y olvido. Madrid, Arrecife/Universidad Autónoma de Madrid, 1999; La memoria, la historia, el olvido. Madrid, Trotta, 2004 [2000].

3 Mabel Cuesta. Inscrita bajo sospecha. Prólogo de Odette Alonso Yodú. Madrid, Betania, 2010; Félix Luis Viera. El Corazón del Rey. Prólogo de Abel German. México, Innovación Editorial Lagares, 2010. [As citações correspondem a estas edições]. Devo esclarecer que, embora o título do livro apareça nesta edição como El Corazón del Rey, o autor insiste na grafia com minúsculas, que utilizo.

4 Mabel Cuesta, Matanzas, Cuba, 1976. Ensaísta, crítica e narradora. Formada me Letras Hispánicas pela Universidad de La Habana, 1999. Livros de contos: Confesiones on line (2003) Cuaderno de la fiancée (2005) e Inscrita bajo sospecha (2010). Aparece nas antologias: Las musas inquietantes (2003); La hora 0 (2005); Havana Noir (2007); Two Shores: Voices in Lesbian Narratives (2008) e Dos Orillas: Voces en la narrativa lésbica (2008). Publica crítica literária em revistas especializadas de Cuba, Estados Unidos, México, Honduras, Canadá, Brasil e Espanha. Atualmente na fase final do doutorado na Universidade da Cidade de Nova 
tos narrativos breves, seduz pela forma elíptica, enxuta, de incessantes transgressões. Nele destaca-se a sensibilidade narrativa para o essencial, a salvo de maneirismos literários, receitas desestruturadoras ou mistérios aparatosos, a eficaz retórica discursiva e uma elaborada composição da história. Com seu ofício fabulador, a autora faz entrar no jogo da memória imaginária, seu atento leitor ao qual é contado e ao discurso rememorativo que o conta.

Para ninguém é um segredo que a narrativa curta, semelhante ao poema, se não acerta no alvo, perde seu percurso. O que é possível consertar em outro capítulo de romance fica perdido em um conto. Calvino, fazendo o elogio da brevidade, argumenta que escrever em prosa não deveria ser diferente de escrever poesia; em ambos os casos é busca de uma expressão necessária, única, densa, concisa, memorável (Calvino, 1998, p. 60). Nessa estética da brevidade, Inscrita bajo sospecha se inscreve. A concisão, carregada de significados, sua integração em um conjunto plurívoco, o envolvente tecido das reminiscências, a linguagem trabalhada em filigrana, sem deixar de ser direto e, por vezes, coloquial, tudo conforma um livro de indagação existencial, na qual a memória suspeitosa tem um papel principal.

E vale recordar, com Paul Ricoeur ${ }^{5}$, que a suspeita arremete contra as máscaras da convivência social, desmantela e questiona, derruba muros ideologizantes, assim como desarticula a falácia da unidade do sujeito. Pensar na dúvida produtiva implica pôr em entredito, indagar no "pode ser" e "talvez não seja", admitir interpretações diversas, afirmando e negando não como dicotomias, mas como polos complementares da ficção concebida no viés da suspeita.

Em relação à composição do livro (entre 2005 y 2006), a autora diz:

Esa circunstancia dolorosísima (el decidir si me marcharía o no) trajo consigo una serie de preguntas mucho más fuertes sobre mi nacimiento, mi devenir como ser humano, como profesional, mi cotidianidad, mi razón de ser y especialmente sobre cómo sentía que en diferentes circunstancias y de manera recurrente se me ha percibido como sospechosa. Un ciclo de sospechas que comenzó el día en que mi padre no me quiso reconocer como hija legítima y que, creía yo, terminaba con esta huida del país [...] Sí, es un libro de autoficción, sin duda alguna. ${ }^{6}$

Na poética narrativa de Mabel Cuesta, sobressai a paixão pela própria vida inscrita e escrita como criação da memória imaginária. Sua metaficção, que tematiza a escritura como âncora identitária, também fica referida ao ato reminiscente que implica e à natureza da escriba. A autora conta integrando autorreflexão e memória de uma maneira questionadora, mérito nada menor quando nos vemos inundados pela moda das narrativas triviais que exibem um ego encantado consigo. Se o estudo de si mesmo constitui um caudal de obras extraordinárias, atualmente assistimos à proliferação de autoficções triviais, correlatos da autoajuda mais comercial, também das biografias, autobiografias e memórias legitimadoras de estilos de vida ou mentalidade, nas quais há uma banalização ou distorção da memória.

York, CUNY. É professora de língua e literatura hispano-americana em Baruch College da CUNY. Reside em Nova York desde 2007.

5 Refiro-me à apresentação que faz Paul Ricoeur de Marx, Nietzsche e Freud como fundadores e mestres do pensamento da suspeita, desenvolvendo una categoria de notável repercussão na cultura contemporânea. Ver: Freud: una interpretación de la cultura. México: Siglo XXI, 2002 [1965] y El conflicto de las interpretaciones. Buenos Aires: Fondo de Cultura Económica, 2003 [1969].

6 Conversação virtual da autora com Mabel Cuesta (8 mar. 2011). 
A narradora de Inscrita bajo sospecha conta fragmentos de uma história de vida, configurando eus e cronotopos diversos em uma autocaracterização de ricas nuances que vai além da autocontemplação para configurar um espaço transnarcisista de explícita dimensão criativa na escritura, espaço também caracterizado pelo cruzamento de fronteiras, motivo de maior relevância no livro. Assim, quem narra em "Como una piedad" se autorretrata de modo visionário: "Atravieso la frontera. Una de ellas. Parece que al final lo he conseguido. Parece que ilumino un sendero o es que estoy realmente iluminada" (p. 49). Nesse espaço alumbrado pela memória de si na escritura, o ser interior se contempla nos seus reflexos tornassóis que sobrepõem e misturam diversos tempos da existência. O passado é revisitado e revivido, o tempo das recordações tem também seu horizonte de espera em uma figuração dinâmica do tempo, própria das escrituras da memória.

As formas autoficcionais de Mabel Cuesta possibilitam a reflexão sobre a pluralidade das envolturas do eu em uma topicalização de si inédita que evidencia a efêmera coerência da figura integrada de autora, narradora e personagens. Sua autoficção suspeitosa é espelho autocriador, muito patente ao se deslocar pelos espaços multiculturais da sua história de vida, articulando e desarticulando sentidos vitais que remontam à infância. De tal forma, o sujeito configura-se nos desdobramentos, duplo de si. Consigo é possível conversar: "Tantos años atrás, navegando las calles de Manhattan, buscando una respuesta para el enigma, tantos años navegando el mundo en esa versión femenina de Marco Polo en que te convertiste por fuerza" (p. 32). Nessa autocaracterização dialógica, reveladoramente ela se diz: "Escribes en la proa de esos barcos enormes que te llevan de una punta a otra en la redondez del mundo. Eres hemisferio, paralelo, huso horario. Eres la mano posada sobre la pluma y el papel, escribiendo cada vestigio" (p. 32), sinalizando o lugar cheio de riscos e fecundo dos trânsitos, onde cada vestígio é escrito e a existência se transmuta em letra, talvez, letra escarlate, signo abrasador da exclusão e diferença.

No vínculo com o Outro e os outros, no olho alheio e da diferença, estrangeira e estranha no sentido literal e metafórico, exilada no reino interior e deslocada nos espaços heterotópicos que tenta habitar, a narradora-protagonista se sabe uma verdadeira alien, como diz no relato "En la oficina", título que nomeia um lugar de coisificação, ainda mais evidente quando se tenta cruzar alguma fronteira. Experimenta o ser migrante em termos geoculturais, mas também como uma experiência íntima de alteridade que leva em si a crise de sentido e a dissociação, a par a graça da compaixão e a piedade.

Esta figura transcultural vive no interior da língua e do imaginário uma trasumância real e simbólica. Nesses contextos da diáspora contemporânea, no produtivo intervalo de identidade/alteridade, reinterpreta o tema clássico de "quem sou?" Está em busca de si, recorrente motivo da literatura moderna que Inscrita bajo sospecha reescreve de modo comovedor e atraente.

Na sequência de leitura dos fragmentos narrativos ou rapsódias, vai-se descobrindo um sujeito ficcional entre o desejo e a angústia, que carrega o pesado fardo do passado. Através das suas mutações, aparece como uma memoriosa jovem mulher, também retratada quando menina, que ama mulheres, viajante e escriba. De sensibilidade migrante, circula entre diversas culturas e modos de ver o mundo, às vezes, em conflito com sua origem cubana e dos nascidos nos anos 70, culturalmente muito ativos nos anos 90 de intensa crise, experiência de formação marcante que reaparece nos textos por reminiscência explícita ou por alusão.

Essa figura inscrita na diferença tem uma mirada perspicaz que vem da sua cultura letrada, da história originária, dos espaços do deambular que deixam nela suas marcas transculturais. Transterrada e errante, conhece variadas formas de marginalidade que lhe dão uma visão mais abrangente, sem deixar de ser desgarrada: sua sensibilidade é alternativa, 
de minorias majoritárias. Entre a culpa e o perdão, entre a piedade e o olvido, navega sem rumo fixo, na única constância da escritura.

Assim, cada um dos fragmentos narrativos aprofunda nos rasgos constitutivos do sujeito que tem diferentes formas de personagem-pessoa e se apresenta de modo performático, na exposição dramática, encenando variadas fases e rostos. Esse sujeito múltiplo tem, primeiramente, a vivencia de uma sociedade fechada, de tolerância oficial escassa ou zero para a diferença; depois, a experiência viajante, que começara antes da partida, mas já na escritura do livro é uma viagem, real e mítica, sem volta, típica da diáspora: "Nada sería como cambiar la historia. Regresar a mi primera forma de ser sobre la Tierra y no tener que buscarla en el espejo acompañada de una vela y tu voz que sigue al ejercicio. Regresar allí y tener el poder de cambiar la génesis" (p. 52), desta forma fala a personagem de "No sin ver la nieve", na consciência do impossível objeto de desejo.

Narradora e personagens, talvez uma com diferentes formas, compartilham a condição inominada e a angústia existencial na agônica busca de si e seu lugar no mundo, mas nem as onipresentes cartografias e escrituras, que têm a forma de um simbólico cadernobitácora, ajudam no dédalo das grandes cidades com suas práticas discriminatórias e a toda-poderosa burocracia. Ela é suspeitosa em duplo sentido, tanto questionadora como questionada na sua "legitimidade", o que acontece de diversas formas, desde violentas (um dos fragmentos, "Vírgenes de Regla", conta o estupro na adolescência) até quase intangíveis, mas devastadoras, que tem a ver com cultura, língua, procedência, orientação sexual. E, embora não expliquem, quiçá em alusão à frequentemente inexplicável trama da vida "real", estes rasgos apontam para algumas das chaves do sujeito de identidade ferida, de memória infeliz que conta, especialmente se reparamos nos contrapontos gerados pela leitura no viés da suspeita.

A escritura não aspira a desmembrar essa figura porque sua condição é fluente, em processo, inconclusa, dialogante com os outros, sobretudo consigo mesma. Mergulhando na situação limite do ser/não ser, no cruzamento de fronteiras literais e simbólicas, mas cada vez mais desmarcadas, na procura angustiosa de reconhecimento, quem conta está longe de simplificar sua história, de moralizar ou se autoexplicar. Mais que eventos, o livro tematiza estados de ânimo, indagações no ser interior na procura das suas traces de identidade. Como indica Odette Alonso, "la anécdota se diluye en un ir y venir del pensamiento" (p. 8), de modo que a escritura é dissonante, descontínua, de movimento subjetivo, polimorfa, indefinida na relação canônica com o gênero, perto da poesia, da bitácora íntima, do testemunho (p. 8).

Todos os textos de Inscrita bajo sospecha se inscrevem no tempo humano, ao rememorar vestígios com a forma de uma narrativa da existência que focaliza momentos definitórios, quando se condensa o viver ou se esvazia de significados, e acontecem as perdas, epifanias e descobertas, ainda que exteriormente pareça não ocorrer nada transcendental. No centro irradiante do livro, o leitor depara-se com o tema da identidade como problema e enigma. Tempo, espaço, sociedade e cultura não são só marcas, de nascimento e existência, mas signos de uma época de crise que parece não ter fim, assumida desde a diáspora de nossos dias com suas distâncias afetivas irrecuperáveis, de desagregação da família, partidas forçadas e impossíveis retornos, experiência a partir da qual têm que ser imaginados outros ciclos de vida.

Se algo caracteriza o sujeito dilacerado é a memória de tempos traumáticos que, sendo tão recorrente na ficção contemporânea, tem conteúdos próprios na literatura cubana com seus diferentes espaços de enunciação. Dessa maneira, cada texto de Mabel Cuesta 


\section{Conexão Letras}

implica um exercício da memória imaginária que muda escalas e perspectivas ao associar diversas temporalidades. Nessa dimensão do imaginário, o sonho se entrelaça com a memória de modo altamente expressivo:

Volvió a despertar del mismo sueño, la angustia acumulada en las manos que aprieta
hasta el dolor. Otra vez la letanía de los soldados a las nueve en la Cabaña: a la ciudad
nadie puede entraaaaar... de la ciudad nadie puede saliiiiiir... Otra vez la pesadilla;
pensar que ha regresado; que no podrá volver a esta su casa construida con partículas
de ciudades extranjeras; que la persiguen jefes de departamento; oficinistas sin ánimo
de poner cuños pertinentes: el amigo del rector que la llama, discreto, cuando baja de
la guagua; que le dice, hemos recibido instrucciones, no podrás hacer el viaje. Una y
otra vez el mismo sueño, la madre a quien parece no importarle el estado carcelario;
que le ofrece la comodidad de la eterna permanencia, formas de experimentar la
dimensión exacta del delirio. Y ella que corre hasta el teléfono, que no puede marcar
los dígitos precisos, que grita amor, no me dejan regresar a nuestras formas. Ella
que patalea, que dice no es posible, solo vine a verlos, debo regresar a mis rutinas,
a mis muchos días de odio en las terminales de trenes y autobuses, a esa mi nueva
mascarada de país. (p. 59)

Em dramática relação com o presente, o passado revivido é cada vez mais alucinado e cobra dimensões fantasmagóricas. Ainda que acordada, a narradora em "De la ciudad" não logra escapar da "isla-recinto" (p. 60). No final, outra voz a consola: "los años irán borrando la recurrencia de ese no ser feliz" (p. 60), mas ela só escuta "sin más, el cañonazo" (p. 60), ritual emblemático da cidade de La Habana. Na verdade, longe da memória-mensagem, estamos em presença de uma memória-diálogo, na qual o tempo pasado é atualizado pela recordação em um ato catártico que transita entre o desespero e a expiação.

A memória de Inscrita bajo sospecha, mais que coletar, transfigura ao dar forma narrativa ao movimento temporal de um sujeito que se autoexamina nos tempos da sua vida. Cada texto segue vestígios, rastros. O desenho do livro é também enredado, incerto, suspeitoso. Qualquer tentativa de conhecimento resulta fragmentária, evasiva, conjetural. E, ante tanta angústia existencial, a escritura projeta-se em um devir de arcanos e incertezas: "Así, nos inventamos ciclos, cabalísticas eternas, puertas que se abren a un mañana prodigioso que sólo vive en la palabra" (p. 31).

Nesse clima, o livro mergulha na dialética de memória-esquecimento, pois só poderá ser olvidado o que deixou suas pegadas, marcas de vida. A autora debate-se:

como puedes ver en el libro, mi piel está muy tatuada. Quisiera olvidar. Creo que es el único camino hacia el perdón verdadero. Pero como también temo a lo que pido (no vaya a serme concedido, decía Santa Teresa de Ávila) padezco un miedo atroz a la falta de memoria, la cual me provoca, a la par que horror, gozos tremendos. Como ves, es un dilema. Y la escritura (como tan claramente se refleja en el par de cuentos de este libro: Escrituras-Borraduras) me salva a ratos. Creo que, como no puedo olvidar, escribir me alivia y ahí voy "del timbo al tambo". ${ }^{7}$

De tal modo, patente na expressão popular del timbo al tambo, indicativa da falta de rumo fixo ou previsível, o livro descreve uma deslumbrante parábola: vai do viés memorial que quer registrar, inscrever tudo, além da escritura inclusive, ao arrasador desejo de "Una

7 Conversação virtual com Mabel Cuesta. 
borradura total de la memoria y los sentidos" (p. 34), como acontece em "Borraduras", relato de ressonância borgeana, a meu ver, de "Las ruinas circulares".

O relato de Mabel Cuesta coloca em um impactante primeiro plano o estado dolorido e jubiloso de não ser: "Y borré, una a una las fronteras." (p. 36). Consciência fantasmal, de sombras avançando no apagamento definitivo, que na narração alcança seu clímax quando, a diferença de "Funes, el memorioso" que se lembra absolutamente de tudo, a personagem, depois de um laborioso processo de autoaniquilação, poderia se dizer de desnascimento, consegue apagar, e de modo significativo sonhando, as marcas da sua história. Então, ao ser possível falar de si como outro, conclui: "Salí a la calle y nadie dijo un nombre que yo reconociera. Caminé durante varios días con sus noches y todo paisaje era nuevo en la mirada. No sé cómo lo hice; pero conseguí volver a casa [...]. Pude morir en paz con la memoria, concedido el borrón que siempre quiso" (p. 37). A personagem-narradora tem una anagnórise na fronteira da morte. Nessa situação limite e limiar, reconhece sua terra prometida do não ser, quiçá forma paradoxal extrema do "difícil perdão" (de novo o eco ricoueriano ${ }^{8}$ ), até de si mesmo e, com isso, abre-se a uma possível reconciliação da memória, a uma memória feliz na benção do olvido.

No seu conjunto, todos os fragmentos narrativos ou rapsódias confluem na fabulação de um sujeito na persecução de seus "possíveis", oferecendo diferentes alternativas para cada ponto nodal. Contudo, o sujeito tem escolha: construir uma identidade narrativa, contando a vida nas discordâncias essenciais, se destruindo com seus contramovimentos de silêncio, esquecimento e apagamento, também se refazendo, se reengendrando na escritura, para executar, no seu conjunto, variações de si mesmo.

Assim, o livro e cada relato mostram estruturações abertas e ambíguas. O eu de "Escrituras", por exemplo, fala obliquamente, alternando autorrevelação e encobrimento: "No hablas del enigma; pero me llevas hasta la puerta del silencio. Es como Delfos, te digo con una leve sonrisa..." (p. 33). E fico com essa imagem do oráculo de Delfos, reinscrita com notável densidade em Inscrita bajo sospecha, símbolo que não deixamos de interrogar na esperança de inalcançáveis respostas.

Da eloquência de Mabel Cuesta, com suas expressivas zonas de silêncio, o livro dá testemunho. De sua inacabada viagem por si mesma na ficção, também, e muito criativamente, enriquecendo nosso mundo de leitores ávidos de ficções que com suas inscrições suspeitosas, sibilinas, nos alumbram no délfico autoconhecimento, no qual memória e imaginação se entrelaçam em uma espiral sem fim.

\section{A memória do tempo reencontrado}

Ao calor da composição de Memórias de Adriano, Marguerite Yourcenar afirma: "No nosso tempo, o romance histórico, ou o que, por comodidade, se admite designar como tal, só pode ser imerso em um tempo reencontrado, tomada de posse de um mundo interior" (Yourcenar, 1995, p. 301). El corazón del rey, o último romance de Félix Luis Viera $^{9}$, suscita reflexões intensas na sua escritura de um tempo reencontrado. Nesse

8 Ver: Paul Ricoeur. La memoria, la historia y el olvido. Madrid: Trotta, 2004.

9 Félix Luis Viera, Santa Clara, Cuba, 1945. Poeta, narrador, jornalista. Publicou os poemários: Una melodía sin ton ni son bajo la lluvia (1976), Prefiero los que cantan (1988), Cada día muero 24 horas (1990), Y me han dolido los cuchillos (1991), Poemas de amor y de olvido (1994), La patria es una naranja (2010); os livros de contos Las llamas en el cielo (1983), En el nombre del hijo (Prêmio da Crítica 1983) e Precio del amor (1990); os romances Con tu vestido blanco (Prêmio Nacional de Romance da União de Escritores e Artistas de Cuba, 1987, e Prêmio da Crítica 1988), Serás comunista, pero te quiero (1995), Un ciervo herido 


\section{Conexão Letras}

sentido, a escolha do ponto de vista pessoal abre possibilidades muito ricas, ao narrar desde o ser interior, aprofundando nas pertenças socioculturais, modos de ver e estar no mundo, aquilo que singulariza o indivíduo na diferença. A escritura da memória recria um tempo vivido. Nele, práxis vital e visão de mundo são configuradas nos seus intrincados nexos. Por exemplo, o erotismo, que, sendo distintivo da obra do autor, se desenvolve com prazer e opulência nesse romance, mostrando a dimensão íntima das personagens, idiossincrasias e imaginários.

El corazón del rey oferece uma visão rememorativa de uma época com marcados efeitos de referência realista. O romance põe em trama agudos conflitos pessoais e sociais na sociedade cubana, entre 1963 e 1969, localizada em Santa Clara:

Se acostumbraba en aquella ciudad de Santa Clara bautizar a asuntos muy disímiles, y aun de dudosa trascendencia, con los nombres de Cubanacán y Cubanicay. Tríos, dúos, cuartetos musicales, plegables, merenderos, revistas, puestos de comida, espectáculos de una sola vez, bares, marcas de cepillos dentales y palanganas, distinciones oficiales, conciertos, circos, vi con estos nombres. Todo por los ancestros. Según se afirmaba, en "la lengua de estas islas", nacán significa medio o en medio, y cuba, ya se sabe [...] Era la gente de aquella ciudad muy dada e estos dos nombres de los ancestros, lo cual dejaba en claro su falta de imaginación. (p. 41)

A cidade tem papel principal; sua cartografia aparece com precisão ilusionista, descritas as práticas sociais, instituições, tipos, ruas, bares, hotéis, lojas, restaurantes, lugares de lazer e trabalho, e de maneira saliente, modos de viver a cidade, seu clima espiritual e sua aura, até criar uma imagem multifacetada. Assim, uma fascinante cidade da memória, que contém o emaranhado tecido social em plena épica revolucionária, é recuperada e refeita pela recordação, para entrar, com sua singular identidade, no imaginário da narrativa cubana.

Nessa cidade perdida que no tempo da escritura-leitura do romance não existe mais, presente por ausência, feita de traces, quem olha e escuta, quem conta e pensa é um sujeito cético, contemplativo, analítico. Entre a vagabundagem e os devaneios, ele está se descobrindo como poeta. Tem uma peculiar escala de valores e maneiras de interpretar o perturbador tempo em que está imerso.

Com seus efeitos de realidade, o romance de Viera leva-me ao conceito de ficção de José Juan Saer, que chama a atenção sobre a diferença de estatutos entre realismo artístico e o que, por convenção, chamamos realidade. Para o escritor argentino, a ficção é uma antropologia especulativa, portanto não pretende saber de antemão como está feita a realidade. E argumenta: "Aun cuando la intención de veracidad sea sincera y los hechos narrados rigurosamente exactos, sólo que no siempre es así, sigue existiendo el obstáculo de la autenticidad de las fuentes, de los criterios interpretativos y de las turbulencias de sentido propios a toda construcción verbal." (Saer, 2004, p. 10).

Lendo o romance de Viera, inclino-me a pensar, com Saer, que na ficção, mais relevante que a verdade - "Nunca sabremos cómo fue James Joyce" (Saer, 2004, p. 9) -,

(2003) e a novela Inglaterra Hernández (1997, reedições em 2003 e 2005). Traduzido em várias línguas, seus textos fazem parte de numerosas antologias. Un ciervo herido circula na Espanha, Porto Rico, México, Itália, e durante cinco meses esteve entre os livros mais vendidos em Miami. Em Cuba, foi diretor da revista Signos, de projeção internacional e dedicada à cultura. Atualmente exerce o jornalismo cultural e político. Desde 1995 reside no México. El corazón del rey tem resenhas de Abel German, Giordano Lupi, Marco Tulio Aguilera, Teresa Dovalpage, Rafael Carralero e Amir Valle. Ver na bibliografia final. 
resulta a verossimilhança, no sentido aristotélico da coerência interna da imagem artística. El corazón del rey tem uma lógica narrativa crível e convincente, de modo que pode dialogar eficazmente com o discurso da história, a sociologia e o pensamento contemporâneo sobre o tema, aportando seus matizes e perspectivas. De mesma maneira, apela à memória e expectativas do leitor interessado nesse tipo de narrativa. $\mathrm{O}$ autor, na descrição realista, também conjectura, questiona, põe em dúvida, arremetendo contra a memória oficial. No romance mergulhamos nas turbulências de sentido, próprias de toda construção verbal, aludidas por Saer, que muito nos dizem sobre o curso da história de uma sociedade. Sua visão desde as marcas da memória pessoal especula em profundidade e de forma abrangente.

No centro da poética narrativa de Viera está a história, tanto no sentido pessoal como social, mas também como é contada. Os narradores da metaficção historiográfica, apaixonados pela narração, colocam em primeiro plano o passo do conhecer ao dizer, privilegiando a subjetividade, as visões contrastantes e as dissonâncias, em uma consistente exploração das formas. Nesse espírito estético, El corazón del rey conta "una historia personal, existencial, íntimamente universal" 10 . Nessa narração, a época chegará depois, segundo o autor, como "en aluvión"11. A micro-história desata a macro-história e o foco situa-se na dissonância entre o sujeito e o processo social através de discursos, com sua prática consequente, em choque irreconciliável. As interpretações colidem no cotidiano, onde as pessoas tocam com suas mãos o abstrato e, às vezes, ininteligível curso da história, tentando identificar os eixos e guinadas fundamentais.

A poética narrativa de Viera privilegia o sujeito que se faz ao contar fases da sua vida. O romance compõe uma identidade narrativa ${ }^{12}$. Percepção e memória entretecem-se nessa identidade que revela o caráter temporal de uma vida humana tecida pela ficção, configurando o sujeito como acontecimento estético. O protagonista inominado de $\mathrm{El}$ corazón del rey conta suas vicissitudes, no seio dos primeiros anos de uma revolução triunfante, sobretudo relativas à liberdade interior. Como o Fray Servando Teresa de Mier de Reinaldo Arenas, "es en ese plano de víctima inconsolable de la Historia, del tiempo", mas também "en medio de situaciones tan extremas que de tan intolerables resultan a veces liberadoras" (Arenas, 2009, p. 21), que a personagem é configurada, evidenciando diversas facetas do real. Suas marcas de vida, disseminadas no texto, que o leitor vai coletando, tornam a história social interpretável, legível, o que em modo algum significa conclusiva, nem limitada a uma representação, das tantas possíveis, especialmente se não perdermos de vista que o passado na ficção é uma construção literária, da qual participa o trabalho da memória imaginária.

O romance ficcionaliza a temporalidade histórica desde a subjetividade de figuras humanas deambulando no labirinto de si mesmas, que é, também, o de uma revolução, cujo movimento, significados e realizações concretas estão em debate. Portanto, resultam essenciais as maneiras de sentir e pensar no meio de grandes comoções e mudanças radicais. Assume-se a sociedade na suas pulsações vitais, concretizada em sujeitos que pensam e discutem não em abstrato, mas comendo, bebendo, fazendo amor e filas para sobreviver no cotidiano massacrante, buscando transcendência ou buscando o pão de cada dia, medrando ou resistindo no centro das turbulências de uma época complicada pelo choque, já ostensivo, das utopias com as práticas sociais.

10 Conversação virtual da autora com Félix Luis Viera (20 de janeiro, 2011).

11 Idem.

12 Ver Paul Ricoeur. Sí mismo como otro. Madrid: Siglo XXI, 1996, e Del texto a la acción. México: Fondo de Cultura Económica, 2001. 
Nesse contexto-práxis dos 60 em Santa Clara, o narrador-protagonista é fabuloso e precário. El corazón del rey tem a forma de um romance de formação e de artista (versão crioula do Bildungsroman e Künstlerroman). Ao mesmo tempo, beira a autoficção, que lhe concede uma qualidade memorial e de testemunho muito apelativa à enunciação de primeira pessoa. O romance não é, no fundamental, de documentação historiográfica, mas do vivido recordado. Ademais, o autor, ao escrever partes significativas de uma história de vida, utilizando parcialmente um material autobiográfico, mantém com os acontecimentos biográficos narrados uma relação de identidade/alteridade, transmutado em outro eu ao se integrar como personagem de ficção, misturadas suas identidades. De certa forma, projeta desejos e aspirações que, talvez, nunca foram "reais", mas definem à pessoa como se o fossem, mostrando o contínuo movimento de se fazer/desfazer.

À semelhança de um herói da alta modernidade, o protagonista quer sentidos em um mundo onde estão se perdendo, embora também seja problemático, pois não está por cima ou fora dessa alienação. Ele carrega muitas das contradições de seu tempo, se bem que não renuncie à busca problemática, como o aconselha seu mestre Robertón Pérez entre o delírio e a morte:

Escúchame bien, que de tantas cosas importantes que te he dicho en la vida, creo que
ésta es la más importante de todas... Escúchame: dedica tu vida a buscar y hallar el
corazón del rey, búscalo siempre, existe, existe, el corazón del rey existe, que esa sea
tu divisa: buscar y hallar el corazón del rey y tomarlo para ti... Si lo hallas, habrás
triunfado y triunfarás toda la vida, ¿entiendes?... (p. 411)

Esse protagonista tem sentimentos contraditórios, próprios dos anos iniciais da revolução e de seus anos, pois é muito jovem e vive sua iniciação como homem, cidadão, artista, com os ritos de passagem. Habita e é habitado pela frustração, pensa por negação e dúvida, mas tem certezas que vêm da sensibilidade poética, da vocação intelectual para o agon e de um entranhável sentido humano - não leu César Vallejo sem consequências -, humanidade nada impoluta, feita de fúrias e misérias, possivelmente as que fizeram almejar uma revolução antes da revolução. Como diz o autor, sua personagem "está en el camino infinito del automejoramiento humano"13.

No seio de grandes tensões, a trama continuamente desafia e desestabiliza, incitando o leitor a recordar seu próprio itinerário vital. E não me refiro só ao significado da história social, um pouco menos enigmático pelos anos transcorridos, ainda que existam tão contrapostas versões e uma guerra da memória entre a legitimação e demonização da revolução, senão à maneira de viver essa história, à participação, às crenças, aos atos de fé, oportunismo e covardia, ressignificados no romance pela memória desde outra dimensão temporal.

El corazón del rey atinge em cheio o coração de cada um, conduz à própria narrativa de vida que toda pessoa tem e continuamente reescreve com a memória, se reinventando. $\mathrm{O}$ leitor faz perguntas cardeais, tanto aquele que tem referência direta, como o que se depara com o tema desde uma relativa exterioridade. Então, qualquer leitor poderá se perguntar sobre a eficácia das utopias, sobre o descompasso entre os ideais e as práticas sociais, sobre as derivas humanas quando as palavras parecem cair no vazio, sobre o direito a ser quem se é, a se afastar, a dissentir. Questões que não estão limitadas a uma geração ou cultura, mas relativas aos significados das pessoas e nas pessoas de uma revolução que põe no centro as aspirações de justiça social e desalienação. Poderia dizer-se, acompanhando a

13 Conversação virtual com o autor. 
lógica do romance, de um tempo de "grandes expectativas" e "ilusões perdidas", motivo da modernidade literária que, desde Balzac e Dickens, não deixa de ser reinterpretado.

Esse choque surdo, mas irreconciliável, com as tendências desumanizadoras do entorno situam o protagonista "fora do jogo", permitindo-lhe assistir de maneira advertida a um teatro de época. Com o desenvolvimento da trama, essa figura principal vai se transformando em uma espécie de consciência crítica que tenta entender e explicar problemas como o dogmatismo, a falta de correspondência entre os fatos e a história oficial, o antagonismo insolvável entre as aspirações pessoais e a política do poder. E quem analisa não é um niilista, nem um típico individualista burguês. Não são "as memórias do subdesenvolvimento" "14, senão as memórias de um ex-cêntrico em relação às estruturas do poder, com sentido crescente de seu lugar de enunciação, palavras e postura vital.

El corazón del rey desenvolve um sutil jogo de temporalidades que vemos por refração, através da consciência rememorativa do autor. Como argumenta Marguerite Yourcenar: "Aqueles que incluem o romance histórico em uma categoria à parte esquecem que o romancista nunca faz mais que interpretar, com a ajuda dos processos de seu tempo, um certo número de fatos passados, de lembranças conscientes ou não, pessoais ou não, tecidas do mesmo material que a História." (Yourcenar, 1995, p. 301). Assim os acontecimentos narrados, neste caso vivenciados pelo autor, localizam-se no presente ou em um passado perfeito muito perto e influente no presente da narração (tempo performático, dramático), com algumas retrospectivas a um passado mais remoto, típicas do tempo narrado. Mas também, e alargando o foco, os conteúdos tornam-se mais complicados com a perspectiva do intervalo entre o tempo romanceado e o tempo da escritura/leitura. Vale reparar nesta declaração metatextual que, embora feita só uma vez, se projeta a todo o texto, modelando as estratégias de recepção: "Dejo constancia para ti, eventual lector en ese futuro que ya será pasado remoto" (p. 157).

Nessa dimensão retrospectiva de mais longo alcance, geralmente implícita no romance, cobram especial relevância os trasfegos da memória que recupera e transfigura as marcas; seleciona e imagina, estabelecendo uma continuidade dinâmica não só entre presente e passado, mas também preconfigurando o que virá, tempo da espera, impossível de imaginar sem a memória. Em relação ao futuro, como esclarece Ricoeur, a orientação é de dupla mão: do passado para o futuro, seguindo a flecha do câmbio, e do futuro para o passado, de acordo ao movimento inverso da espera para a lembrança, através do presente vivo (Ricoeur, 2003, p. 130).

Se reparamos no lapso que medeia entre o tempo da escritura e o dos acontecimentos, sobressai a efetiva amálgama do horizonte do narrador, a personagem atuando e o autor que escreve. O mais de meio século transcorrido, tempo vivo do presente perpétuo da leitura, faz o romance ainda mais envolvente. Segundo Viera, "Los tiempos que se cruzan son los de aquellos asuntos de la década de 1960, autoralmente hablando, y la mirada hacia atrás, que no se ve, pero que es una ventaja del autor cuando el narrador vaticina el desastre, que ya ha ocurrido cuando el autor comienza la novela." 15

Assim, esse autor-narrador-protagonista está em posição privilegiada para, desde seus diferentes tempos e sua acentuada marginalidade, ver além. Como Tirésias, é diferente, sua relativa cegueira existencial confere o dom do vaticínio, descifrando traces. Escutado hoje, percebe-se mais nitidamente seu tom profético, de augúrios agoureiros:

14 Aludo ao filme Memorias del subdesarrollo (1968) de Tomás Gutiérrez Alea, baseado no romance homônimo de Edmundo Desnoes, um clássico da cultura cubana sobre o tema.

15 Conversação com o autor. 
El caos de lo habitual, que traza una épica de lo cotidiano que tal vez no sea registrada en ningún libro - porque estos se dedican fundamentalmente a la épica de las armas, o, en general, a aconteceres supuestamente menos nimios-, requiere de un tesón para vencer el Absurdo, que estará más allá de la resistencia de muchos seres cuyas vidas, de principio a final, en este devenir socialista, se convertirán en uno de los más pulidos emblemas de la zozobra. Y, según lo que se anuncia, podrán irse por este camino de la angustia sin final varias generaciones. (p. 415)

O romance de Viera lembra-me $A$ montanha mágica, até Hans Castorp anda por uma das suas páginas. Bildungsroman, busca de valores de um herói problemático, ideologias em debate. E não o aponto para diminuí-lo na comparação com uma obra magistral, mas para referi-lo a uma genealogia, a uma tradição criativa na qual os romances se articulam, dizem o que têm que dizer de maneira original, como o faz El corazón del rey. Nesse diálogo com uma tradição narrativa, sobressai sua visitação do cotidiano, espaço privilegiado da memória, e o dessacralizante humor, por momentos, humor negro. O romance pede ser lido com um olho que chora e outro dando risadas, até para o leitor se salvar da autocomiseração. Sua leitura é um banquete cubano, de frutos humildes, minimalistas, se bem suculentos, porque menos pode ser mais, quando trabalhado dessa forma. Dentro de tanto desaforo, deslinguado, iconoclasta, jocoso e irreverente, faz-nos participar em uma portentosa conversação interminável sobre o também inacabado processo da história.

Viera é brilhantemente reflexivo, de pensamento polêmico consistente. Sua recriação memorial é uma construção trans-psicológica do intelecto que não só subjetiviza, mas temporaliza o mundo narrado, sem deixar de ser um poderoso fator de consciência pessoal. Desse modo, El corazón del rey recolhe uma boa parte dos discursos de época, o que foi dito no discurso doutrinário com seus dogmas e repetições extenuantes, porque o sujeito - a muito ilustrativa situação do protagonista - deve ser esclarecido, recrutado, salvado, reprimido, assustado. Simultaneamente, e em contraponto, está a fala desse protagonista com sua autêntica vibração humana, assim como a de outras vozes singulares que matizam. Tanto seus argumentos, enriquecidos pelas variações temáticas de Robertón (com seus apuntes) e a Samaritana (com seu antológico manuscrito real-delirante das filas), como os dos antagonistas (Benito de Palermo, Magalí, Maritza), são desenvolvidos por extenso. O texto, sendo de pensamento, faz pensar ao leitor, mobilizando sua memória, horizonte moral e experiência.

Com suas vozes plurais, as personagens argumentam, replicam e contrarreplicam. Suas interpretações do que estão vivendo dariam inveja a não poucos hermeneutas de profissão. Assim sucede com a Samaritana (um travesti) e Robertón Pérez (alcoólatra envolvido no mercado negro), filósofos da existência, populares e da tradição oral, transgressivos e ambivalentes, que vivem no limite com uma lucidez assombrosa. Seu saber não foi canonizado por nenhuma academia, mais que a do cotidiano e a picaresca, engenhosos e divertidos, não poucas vezes, patéticos ou grotescos.

Nesse âmbito, a fala resulta deslumbrante pela fluência poderosa e diversificados registros, fazendo realidades. As personagens falam sobre e com a história, desde outra sensibilidade, humanamente, sobrevivendo na malandragem do pícaro revisitado, portanto, sem moralizações hipócritas nem declarações grandiloquentes, ao dar corpo de palavras a temas de envergadura universal: a amizade, o amor, a busca de sentido. E porque não alienaram o vínculo com a vida como ela é, falam de uma maneira esclarecida, brincalhona, dramática. Suas palavras têm substância e ressonância.

No incessante "falar a época", é recorrente a reflexão sobre o curso da história 
social que as personagens, e na trama no seu conjunto, interpretam como um tempo que não chegou a ser, nem será. Significativamente esse tempo perdido não é narrado desde a nostalgia (ponto de vista que já deu seus melhores frutos na literatura do exílio cubano), embora se configure como um mundo declinante, onde tudo está acabando quando, em teoria, devia começar; mundo no qual muitos emigram ou se querem ir, morrem ou estão ficando mudos porque não há espaço real para serem ouvidos e participar, ou já não se tem nada que dizer.

O romance marca um ponto de giro na cultura literária cubana pela mirada iconoclasta, libertadora. Poucas vezes a literatura atual logrou ir tão fundo na consciência individual dilacerada com sua crítica candente desde a pessoa em crise, a qual a duras penas logra ser e se expressar. Desde o ser interior, uma época paradoxal está aqui fabulada, época sobre a qual é vital escrevermos e lermos. Por outra parte, o romance nos deixa livres para criar nossa própria memória. Seus questionamentos permitem nos reconhecermos imperfeitos, limitados, frágeis, vislumbrando outras possibilidades na ficção inesgotável, se bem tão relativas e incertas como qualquer obra humana.

Dominantemente memorialista, mas sem pretensões de dar conta de uma sociedade em um metarrelato totalizante, Viera recria, ¿exorciza?, a memória ferida. El corazón del rey indaga nas tremendas implicações morais e criativas de um "difícil" tempo humano. Romance de densidade da memória e reflexiva admiráveis, ao mesmo tempo leve, lúdico, de celebração da fala desatada. Surpreendente pela sua iluminação de novas dimensões da história e a recusa a resolver as contradições, como se poderia ler neste final antiépico com sua forma elíptica, quem sabe alusiva à impassível continuidade da vida no meio de tanto Absurdo: "Mira, está lloviznando" (p. 515).

\section{Final provisório e promissório}

Sem pretender comparar dois textos de diferenciada estética e poética narrativa, cujos autores pertencem a distintas gerações e ficcionalizam diversas temporalidades, se bem lidos de forma relacional podem dialogar de maneira muito sugestiva, destacaria como a literatura cubana mais recente, mergulhando na memória individual, está contribuindo à configuração de uma memória compartilhada de variados matizes, contestatória, controversa. Fazer memória em Inscrita bajo sospecha e El corazón del rey gera novos espaços de experiência, expressivos da condição dos autores em diáspora, viajantes que carregam consigo as memórias, jubilosas e doloridas, de seus trânsitos a partir de uma origem que terá sempre algo de mítico, entre saudade e tormento. Rememorar faz possível, a par um horizonte de espera, precário e provisório, mas vivo.

Então, resulta principal o papel da memória que, longe de ser um depósito de fatos passados, traz consigo mediação e reconstrução: reinvenção. A escritura da memória implica uma amálgama de múltiplas e contraditórias versões, que responde ao vivido, coletado, herdado (O'Reilly Herrera, 2007, p. 186). Nessa heterogeneidade das discrepantes histórias e práticas discursivas que nos constituem, a cultura cubana desenvolve sua complexa continuidade de nação viajante.

Vai-se integrando, assim, um repertório narrativo, sobretudo na clivagem entre a memória oficial, enquadrada e dominante, e as memórias subterrâneas de sujeitos marginalizados, periféricos, assinalados pela diferença. Essa memória alternativa, com suas zonas de silêncio eloquente, entra no fluxo, já sem fim, das memórias soterradas que voltam à luz na ficção contemporânea. 


\section{Conexão Letras}

As narrativas da memória em tempos transnacionais e desde a experiência diaspórica de nossos dias oferece novos conteúdos e tem outras abrangências. Com variadas formas criativas, a memória ferida está sendo escrita, e não só pelos textos literários e artísticos, como parte de um processo de identificação fundamental para toda cultura e muito produtivo na cubana contemporânea na sua multifacetada composição, inclusiva de Ilha e diáspora, embora essa escritura abra perguntas para as quais, autores e leitores, não temos respostas definitivas, somente representações, talvez promissoras de uma memória reconciliada, memória do porvir. Poder-se-ia dizer que, ao recriar vestígios temporais da maior repercussão humana, a narrativa cubana de hoje ensaia, oferecendo interpretações instigantes e iluminadoras.

\section{Referências}

AGUILERA, Marco Tulio. El corazón del rey de Félix Luis Viera. Disponível em: http://www.cubaencuentro.com/cultura/articulos/el-corazon-del-rey-de-felix-luis-viera254176. Acesso em: 5 mar. 2011.

ARENAS, Reinaldo. El mundo alucinante. México: D. F. Tusquets, 2009. CALVINO, Ítalo. Seis propuestas para el próximo milenio. Madrid: Siruela, 1998.

CARRALERO, Rafael. Morando al corazón del Rey. Disponível em: http://grafoscopio.blogspot.com/2011/03/rafael-carralero-morando-al-corazon-del.html. Acesso em: 14 fev. 2011. CUESTA, Mabel. Inscrita bajo sospecha. Prólogo de Odette Alonso Yodú. Madrid: Betania, 2010.

DOVALPAGE, Teresa. Las arterias sangrantes de El Corazón del Rey. Disponível em: http://eriginalbooks.com/?p=590. Acesso em: 10 mar. 2011.

GERMAN, Abel. La memoria de un hombre sin rostro. Disponível em: http://www. cubaencuentro.com/cultura/articulos/la-memoria-de-un-hombre-sin-rostro-247025. Acesso em: 5 fev. 2011.

LUPI, Giordano. Félix Luis Viera - El corazón del rey. Disponível em: http://www. liberolibro.it/felix-luis-viera-el-corazon-del-rey/. Acesso em: 5 mar. 2011.

O'REILLY HERRERA, Andrea. The Politics of Mis-ReMembering: History, Imagination and the Recovery of The Lost Generation. In: O'REILLY HERRERA, Andrea (Ed.). Cuba: Idea of a Nation Displaced. New York: SUNY Press, 2007. p. 173-193. RICOEUR, Paul. Sí mismo como otro. Madrid: Siglo XXI, 1996. . Une réponse de Paul Ricoeur. In: JOY, Morny (Ed.). Paul Ricoeur and Narrative. Context and contestation. Calgary: University of Calgary Press, 1997. p. xlv-lv. . La marque du passé. Revue de Metaphysique et de Morale, n. 1, p. 7-31, 1998. . La lectura del tiempo pasado: memoria y olvido. Madrid: Arrecife/Universidad Autónoma de Madrid, 1999. . Del texto a la acción. México, D. F.: Fondo de Cultura Económica, 2001. . Freud: una interpretación de la cultura. México, D. F.: Siglo XXI, 2002. . El conflicto de las interpretaciones. Buenos Aires: Fondo de Cultura Económica, 2003. La memoria, la historia, el olvido. Madrid: Trotta, 2004.

SAER, José Juan. El concepto de ficción. Buenos Aires: Seix Barral, 2004.

VALLE, Amir. La memória de lo que se ha perdido. Culturamas Espanha [no prelo] VIERA, Félix Luis Viera. El Corazón del Rey. Prólogo de Abel German. México: Innovación Editorial Lagares, 2010.

YOURCENAR, Marguerite. Caderno de notas. In: . Memórias de Adriano. Rio de Janeiro: São Paulo: Record, 1995 